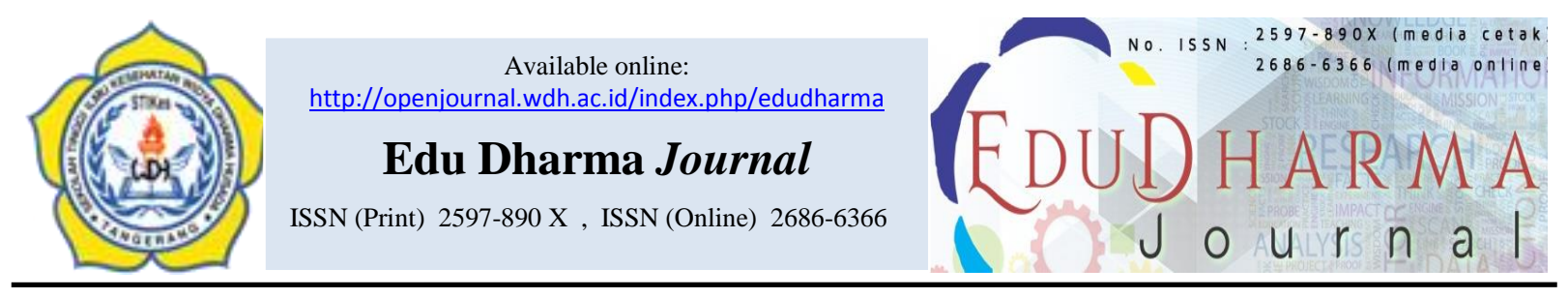

\title{
HUBUNGAN PENDIDIKAN DENGAN PERILAKU DETEKSI DINI KANKER SERVIKS PADA WANITA DI KELURAHAN KEBON KALAPA BOGOR
}

Ikada Septi Arimurti $^{1^{*}}$ Nurfitri Kusumawati ${ }^{2}$, Sri Haryanto ${ }^{3}$

STIKes Widya Dharma Husada Tangerang, Jalan Pajajaran No.1, Pamulang, Tangerang Selatan 15417, Indonesia

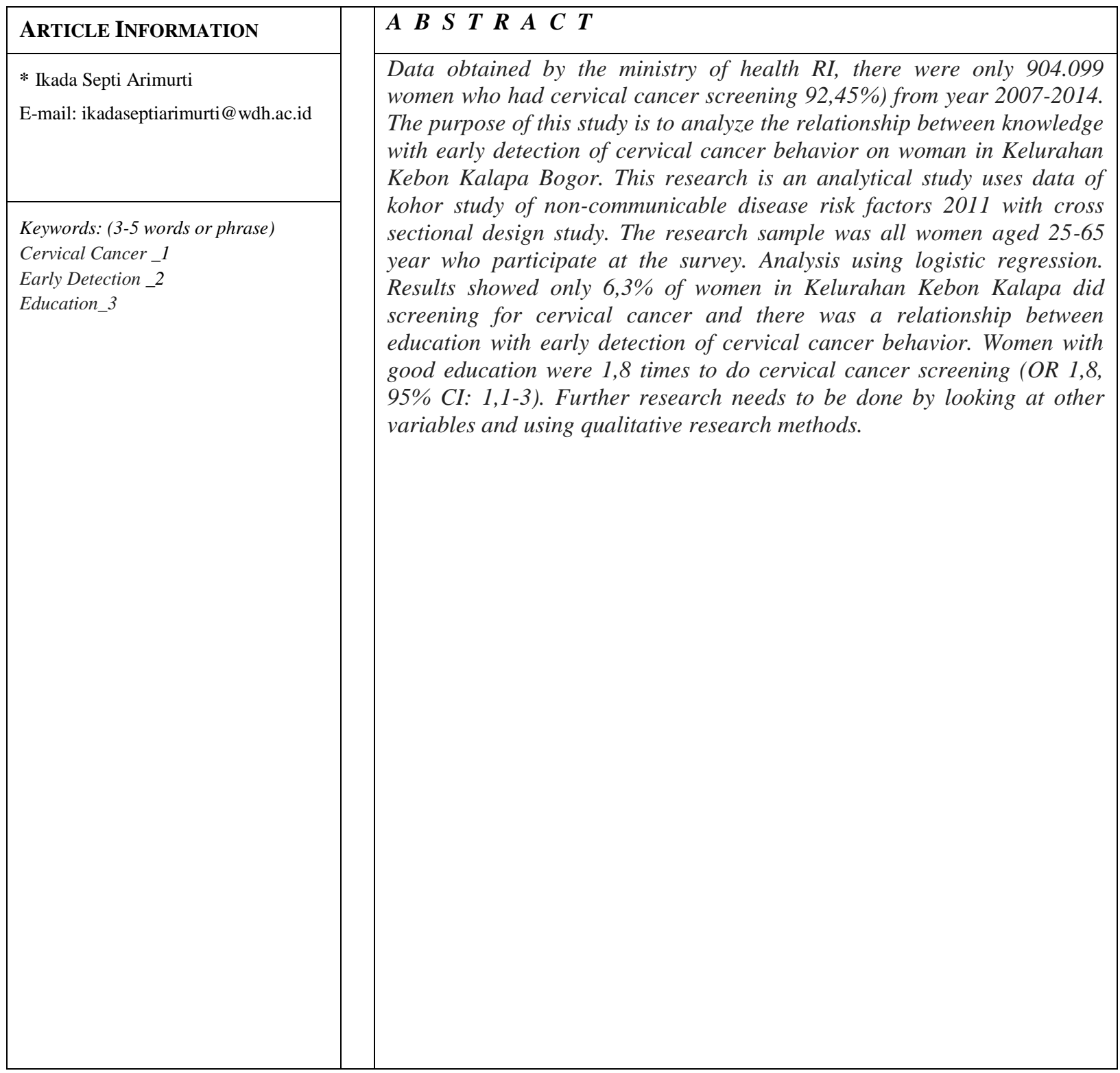




\begin{tabular}{|c|c|}
\hline & $\begin{array}{l}\text { A B S T R A K } \\
\text { Latar belakang: Masa transisi dari masa kanak-kanak menjadi dewasa } \\
\text { adalah tahapan masa remaja. Masa ini ditandai sejumlah perubahan } \\
\text { biologis, kognitif, dan emosional (Muljati et.al, 2016). Menstruasi yang } \\
\text { dialami remaja putri setiap bulannya dan pola konsumsi yang terkadang } \\
\text { melakukan diet sehingga semakin sedikit asupan zat besi yang dapat } \\
\text { memenuhi kebutuhan mereka dapat menyebakan terjadinya anemia } \\
\text { (Martini, 2015). Menurut data Riskesdas (2018), prevalensi anemia di } \\
\text { Indonesia yaitu } 48,9 \% \text { dengan proporsi anemia pada kelompok umur } 15- \\
24 \text { tahun dan } 25-34 \text { tahun (Kemenkes RI, 2018). Prevalensi anemia pada } \\
\text { remaja putri tahun } 2017 \text { dalam Profil Kesehatan Kota Depok diketahui } \\
34,5 \% \text { remaja putri yang mengalami anemia (Profil Dinkes Kota Depok } \\
2017) \text {. Tujuan penelitian: untuk mengetahui adanya hubungan antara } \\
\text { pengetahuan dan sikap remaja putri serta paparan media informasi } \\
\text { terhadap perilaku pencegahan anemia. Metode: Penelitian ini } \\
\text { menggunakan metode kuantitatif analitik ini menggunakan desain cross } \\
\text { sectional. Jumlah sampel sebanyak } 81 \text { orang di SMA Muhammadiyah } 04 \\
\text { Depok. Hasil penelitian diperoleh remaja usia } \leq 16 \text { tahun sebanyak } 52 \\
\text { (64,2\%) dan >16 tahun 29 (35,8\%). Responden yang memiliki } \\
\text { pengetahuan kurang sebanyak } 54(66,7 \%) \text {, responden yang memiliki sikap } \\
\text { kurang sebanyak } 31 \text { (38,3\%) dan responden dengan paparan media } \\
\text { informasi kurang baik sebanyak } 60(74,1 \%) \text {. Hasil uji statistic pengetahuan } \\
\text { tentang anemia (p=0,621, p>0,05), sikap terhadap pencegahan anemia } \\
\text { (p=0,432, p>0,05) dan paparan media informasi tentang pencegahan } \\
\text { anemia (p=0,796, p>0,05) maka dapat diartikan tidak memiliki hubungan } \\
\text { yang signifikan. Melalui promosi kesehatan tentang upaya pencegahan } \\
\text { terhadap anemia dapat meningkatkan kesehatan fisik dan kematangan } \\
\text { reproduksi dari remaja. }\end{array}$ \\
\hline & This is an open access article under the $\mathrm{CC}-\mathrm{BY}-\mathrm{NC}-\mathrm{SA}$ license. \\
\hline & 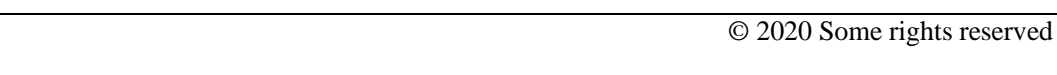 \\
\hline
\end{tabular}




\section{PENDAHULUAN}

Kanker serviks merupakan salah satu penyakit yang banyak dialami oleh kaum wanita di dunia, khususnya wanita dinegara bekembang. Berdasarkan Rilis WHO (World Health Organization) tahun 2014, menyatakan kanker serviks berada pada peringkat kedua dibawah kanker payudara. Jumlah kasus baru yang ditemukan di seluruh dunia sebanyak 528.000 kasus pada tahun 2012. Sebagian besar atau $85 \%$ kejadian terjadi di negara berkembang. Untuk wilayah South East Asia Region (SEARO) sendiri, angka kejadian kanker serviks sebesar 175 per 1.000 penduduk. (IARC, 2012; WHO, 2014; Kemenkes RI, 2015).

Data dari Globacan (2012) yang mengatakan bahwa di Indonesia peringkat kedua kanker yang di idap oleh wanita di Indonesia adalah kanker serviks, dengan angka insiden 20.928 kasus atau 17 per 100.000 wanita. Dimana angka kejadian tersebut berada diatas rata-rata angka kejadian di dunia bahkan di Asia Tenggara. Sedangkan angka kematiannya sebesar 10 per 100.000 wanita. Data di atas menggambarkan bahwa angka kejadian, kesakitan maupun kematian cukup tinggi, sehingga diperlukan penanganan yang lebih awal dan serius untuk menanggulangi hal ini (Globacan, 2012; ICO, 2014).
Tingginya kejadian kanker serviks pada perempuan, disebabkan oleh adanya infeksi Human Papillomavirus (HVP) tipe 16 dan 18. Virus ini bersifat kronis, artinya dapat membentuk kanker setelah 10 hingga 20 tahun. Selain faktor penyebab langsung kanker serviks, ada beberapa faktor yang dinilai sebagai kofaktor atau faktor yang mempermudah terjadinya kanker serviks, antara lain melakukan aktifitas seksual pada wanita usia muda (dibawah 20 tahun), sering melakukan aktifitas seksual dengan pasangan yang berbeda (multiple partner), riwayat infeksi pada daerah kelamin atau radang panggul, wanita perokok aktif dan status sosial ekonomi yang rendah. (Depkes, 2009; Kemenkes RI, 2010).

Pencegahan sekunder menurut Depkes RI (2009) berlaku dua cara deteksi dini berupa pap smear dan juga IVA tes. Penggunaan pemerikasaan sitologi untuk mendeteksi kanker serviks atau disebut pap smear, dan pemeriksaan ini menjadi standar dalam pencegahan dini kanker serviks. Tingkat sensitifitas pap smear sebesar $55 \%$ dan spesifisitasnya $90 \%$. Berbeda Sedangkan IVA tes merupakan pemeriksan langsung bukan pemeriksaan sitologi seperti pap smear. Cara yang dilakukan dalam pemeriksaan ini dengan mengoleskan asam asetat $3-5 \%$ di permukaan portio. Hasil pemeriksaan akan mendeteksi kanker serviks jika terdapat 
gambaran acetowhite (bercak putih) yang kasat mata. Dimana angka spesifisitas IVA adalah $99,8 \%$ dan sensivitasnya adalah 90,9\% (Hanafi, dkk, 2003;Wiyono, dkk, 2008; Tilusari,2014; Susilowati 2014).

Perilaku deteksi dini kanker serviks pada perempuan di Indonesia masih sangat rendah, diperkirakan hanya sebesar 5\% dengan pap smear dan juga IVA tes padahal target cakupan deteksi dini kanker serviks pemerintah Indonesia yaitu $85 \%$ dari seluruh perempuan di Indonesia (Damailia, 2014). Hal tersebut sesuai data yang didapatkan dari Dinas Kabupaten Karawang (2013) yang dikutip oleh Mulyati, dkk (2015) bahwa cakupan tes IVA di Kabupaten Karawang hanya mencapai 20,6\%, sedangkan target di Kabupaten Karawang sebesar 80\%. Hasil yang hampir serupa didapat Dewi (2012) yang melakukan penelitian di Puskesmas Glugur Darat Kota Medan, didapatkan hasil bahwa pada tahun 2012 hanya sekitar $1,31 \%$ wanita dengan pasangan pernah melakukan pap smear.

Rendahnya deteksi dini kanker serviks disebabkan terbatasnya akses skrining, pengobatan dan juga kesadaran wanita Indonesia yang masih rendah. Sebagian besar wanita Indonesia memiliki akses yang sedikit (limited access) terhadap informasi maupun pelayanan penyakit kanker serviks, hal ini disebabkan rendahnya tingkat ekonomi maupun tingkat pendidikan wanita yang rendah tentang deteksi dini melalui pap smear tes ataupun IVA tes (Depkes RI, 2008; Damailia, 2014). Hal yang berbeda terjadi di negara maju, seperti misalnya Amerika Serikat. Angka insiden kanker serviks dalam 50 tahun terakhir mengalami penurunan sekitar $70 \%$. Program deteksi dini dan penanganan yang baik menjadi penyebab penurunan tersebut. Hal tersebut sesuai dengan penelitian yang dilakukan oleh Peirson (2013), penelitian melalui metode systematic review dengan data periode tahun 1995 hingga 2012. Hasil penelitiannya menunjukkan bahwa angka kejadian kanker serviks dan tingkat kematian akibat kanker serviks dapat diturunkan melalui deteksi dini lesi prakanker.

Salah satu faktor yang berhubungan dengan perilaku deteksi dini terhadap kanker serviks adalah pendidikan. Menurut penelitian yang dilakukan oleh Ningrum (2012) di Kabupaten Banyumas menyatakan bahwa terdapat hubungan yang signifikan antara tingkat pengetahuan ibu dengan perilaku ibu untuk mengikuti deteksi dini kanker serviks ( $p$ value 0,001). Begitu juga dengan Taherian (2002) dalam penelitiannya di Iran yang menyatakan bahwa ibu dengan tingkat pendidikan yang rendah mempunyai peluang menderita kanker serviks sebesar 2 kali lebih besar. Hal ini disebabkan ibu dengan pendidikan 
rendah berhubunggan dengan tingkat pengetahuannya dan kesadarannya akan pentingnya kesehatan.

\section{METODE PENELITIAN}

Penelitian ini merupakan studi analitik yang dioleh dari data sekunder yang berasal dari Badan Litbangkes Kemenkes RI. Penelitian ini menggunakan cross sectional methods sebagai desain penelitian. Dalam penelitian ini akan ditelusuri hubungan pengetahuan dengan perilaku deteksi dini kanker serviks. Cross sectional methods adalah penelitian observasional untuk mengetahui dinamika korelasi antara faktor-faktor risiko dengan penyakit atau status kesehatan tertentu melalui model pendekatan point time. Keseluruhan variabel tersebut akan diobservasi dalam periode waktu yang sama.

\section{HASIL PENELITIAN}

\section{A. Perilaku Deteksi Dini Kanker Serviks}

Tabel 1.Perilaku deteksi dini kanker serviks

\begin{tabular}{lll}
\hline $\begin{array}{l}\text { Perilaku Deteksi } \\
\text { Dini }\end{array}$ & Frekuensi & $\begin{array}{l}\text { Persentase } \\
(\%)\end{array}$ \\
\hline $\begin{array}{l}\text { Pap Smear } \\
\text { Melakukan }\end{array}$ & 71 & 5,8 \\
$\begin{array}{l}\text { Tidak melakukan } \\
\text { IVA tes }\end{array}$ & 1155 & 94,2 \\
$\begin{array}{l}\text { Melakukan } \\
\text { Tidak melakukan }\end{array}$ & 16 & 1,3 \\
$\begin{array}{l}\text { Perilaku deteksi dini } \\
\text { kanker serviks }\end{array}$ & 1210 & 98,7 \\
$\begin{array}{l}\text { Melakukan } \\
\text { Tidak melakukan }\end{array}$ & 77 & \\
\hline
\end{tabular}

Berdasarkan tabel 1. terlihat bahwa responden yang sebelumnya melakukan metode pap smear sebanyak 5,8\% dan dengan metode IVA tes sebanyak 1,3\% sebagai tindakan deteksi dini kanker serviks. Sedangkan sebanyak sebanyak $6,3 \%$ melakukan kedua tes tersebut sebagai deteksi dini kanker serviks.

\section{B.Perilaku Deteksi Dini Kanker Serviks} Menurut Pendidikan

Tabel 2. Perilaku deteksi dini kanker serviks menurut pendidikan

\begin{tabular}{|c|c|c|c|c|c|}
\hline Variabel & $\begin{array}{l}\text { Perilaku } \\
\text { dini } \\
\text { Ya }\end{array}$ & $\begin{array}{l}\text { deteksi } \\
\text { Tidak }\end{array}$ & OR & $\begin{array}{l}95 \% \\
\text { CI }\end{array}$ & $\begin{array}{l}\text { Nilai } \\
\text { p }\end{array}$ \\
\hline \multicolumn{6}{|l|}{ Pendidikan } \\
\hline Tinggi & $\begin{array}{l}10 \\
(20,4 \%)\end{array}$ & $\begin{array}{l}39 \\
(79,6 \%)\end{array}$ & $1,8 *$ & $\begin{array}{l}1,1- \\
3,0\end{array}$ & 0,016 \\
\hline Menengah & $\begin{array}{l}30 \\
(8,1 \%)\end{array}$ & $\begin{array}{l}339 \\
(91,9 \%)\end{array}$ & $5,3 *$ & $\begin{array}{l}2,4- \\
11,5\end{array}$ & 0,000 \\
\hline Rendah & $\begin{array}{l}37 \\
(4,6 \%)\end{array}$ & $\begin{array}{l}771 \\
(95,4 \%)\end{array}$ & & & \\
\hline
\end{tabular}

Pada penelitian ini bertujuan untuk mengetahui korelasi antar variabel pendidikan sebagai independent variable dan perilaku deteksi dini kanker serviks sebagai dependent variable. Penggunaan uji chi square pada penelitian ini dilakukan karena variabelnya bersifat kategorik dengan tingkat kemaknaan $5 \%$. Berdasarkan tabel 2. analisis hasil pengolahan data menunjukkan terdapat hubungan yang bermakna antara pendidikan dan perilaku deteksi dini kanker serviks ( $p$ value 0,000). Dimana wanita yang pendidikannya menengah berpeluang 5,3 kali melakukan deteksi dini 
kanker serviks jika dibandingkan dengan wanita dengan pendidikan rendah (CI 95\% $1,9-9,5)$.

\section{PEMBAHASAN}

\section{Perilaku Deteksi Dini Kanker Serviks} Penelitian yang dilakukan di luar negeri seperti yang dilakukan terhadap wanita keturunan asia yang tinggal di Amerika, menunjukkan hasil pada wanita Korea hanya $13 \%$ yang melakukan pap smear tes sedangkan pada wanita Vietnam lebih rendah yaitu sebesar $10 \%$ yang melakukan pap smear tes (Gor Beverly J et al, 2011). Sama halnya dengan wanita di Slovakia, hanya sekitar $20 \%$ saja yang ikut berpartisipasi dalam acara deteksi dini kanker serviks (Szaboova V, 2014). Di Indonesia hingga tahun 2013, dari sebanyak 9.422 Puskesmas hanya 717 Puskesmas atau 7,6\% yang baru menyelenggarakan program deteksi dini kanker serviks. Data ini diperoleh dari data rutin yang dikeluarkan Kementerian Kesehatan RI. (Kemenkes RI, 2015).

Hasil pada penelitian ini dimana rendahnya angka deteksi dini kanker serviks dimungkinkan karena pemeriksaan IVA tes merupakan metode deteksi dini yang baru saja dikenal, sehingga masyarakat belum terlalu terpapar oleh hal ini. Sedangkan untuk pap smear sendiri adalah pemeriksaan yang hanya dapat dilakukan di fasilitas kesehatan yang lebih tinggi dari Puskesmas dan biaya yang dibutuhkan lebih besar apabila dibandingkan metode pemeriksaan lain yaitu IVA tes. Banyak faktor lain pula yang turut berperan dalam perilaku deteki dini kanker serviks seperti budaya malu yang masih sangat kental pada wanita di Indonesia dimana mereka biasanya akan merasa malu untuk memeriksakan bagian kelaminnya, apalagi jika tenaga kesehatan yang memeriksanya adalah pria, selain itu bisa juga berasal dari tenaga kesehatan yang belum berkompeten untuk melakukan pemeriksaan deteksi dini dan juga fasilitas pelayanan kesehatan yang memang belum tersedia.

\section{Perilaku Deteksi Dini Kanker Serviks}

\section{Menurut Pendidikan}

Berdasarkan tabel 2. analisis hasil pengolahan data menunjukkan terdapat hubungan yang bermakna antara pendidikan dan perilaku deteksi dini kanker serviks (p value 0,000). Dimana wanita yang pendidikannya menengah berpeluang 5,3 kali melakukan deteksi dini kanker serviks jika dibandingkan dengan wanita dengan pendidikan 
rendah (CI 95\% 1,9-9,5). Hasil penelitian ini tidak sesuai dengan penelitian Yuliawati (2012) yang dilakukan di Kabupaten Kebumen. Hasil penelitian tersebut menyatakan tidak terdapat hubungan yang bermakna (signifikan) antara pendidikan seorang wanita dan perilaku deteksi dini kanker serviks melalui metode IVA. Begitu juga dengan penelitian oleh Wahyuni (2013) yang dilakukan di Kecamatan Ngmpel Kabupaten Kendal. Hasil penelitian menyatakan bahwa tidak ditemukan hubungan yang bermakna antara pendidikan dan perilaku deteksi dini kanker serviks ( $p$ value 0,392). Hal yang sama dengan penelitian yang dilakukan oleh Gustiana dkk (2014) terkait variabel-variabel yang berhubungan dengan perilaku deteksi dini kanker serviks, didapatkan hasil bahwa pendidikan tidak secara bermakna berhubungan dengan perilaku deteksi dini kanker serviks ( $p$ value 1,000; 95\% CI 0,07-9,96). Berbeda dengan tiga penelitian yang disebutkan sebelumnya, penelitian Ningrum (2012) di Kabupaten Banyumas menyatakan terdapat hubungan signifikan antara tingkat pengetahuan ibu dan perilaku ibu untuk mengikuti deteksi dini kanker serviks ( $p$ value 0,001 )

Taherian (2002) dalam penelitiannya di Iran yang menyatakan bahwa pendidikan ibu yang rendah mempunyai peluang 2 kali lebih besar menderita kanker serviks. Hal ini disebabkan ibu dengan pendidikan rendah berhubungan dengan tingkat pengetahuannya dan kesadarannya akan pentingnya kesehatan. Penelitian Caiyan $\mathrm{Xu}$ et al (2011) di Beijing juga mengatakan bahwa tingkat pendidikan berpengaruh terhadap perilaku deteksi dini. Wanita yang memeriksakan diri untuk mendeteksi kanker serviks secara dini lewat tenaga kesehatan berasal dari kalangan dengan pendidikan yang tinggi, hampir sebagian besar lulusan diploma. Sama halnya pada penelitian Ostensson et al (2014) berkesimpulan bahwa terdapat hubungan signifikan antara pendidikan dan perilaku deteksi dini kanker serviks $(p<0,05)$. Begitu juga dengan wanita di Slovakia, wanita dengan pendidikan yang lebih tinggi melakukan deteksi dini secara regular dan mempunyai tingkat pendidikan lebih baik tentang pencegahan terhadap kanker serviks (Szaboova V et al, 2014).

Pendidikan tinggi akan mempengaruhi pola pikir seseorang untuk mengambil keputusan. Begitu juga dengan keputusan yang berhubungan dengan kesehatan seseorang. Dengan pendidikan yang tinggi, maka semakin banyak informasi yang seharus bisa ia 
dapatkan, bisa melalui lingkungan tempat ia bekerja, media elektronik, media sosial, tenaga kesehatan dan juga teman dan anggota keluarga terdekat.

\section{KESIMPULAN}

1. Cakupan perilaku deteksi dini kanker serviks di Kelurahan Kebon Kalapa Bogor adalah 6,3\% wanita.

2. Ditemukan hubungan yang bermakna (signifikan) antara variabel pendidikan dan perilaku deteksi dini kanker serviks, hasil penelitian menunjukkan wanita yang pendidikannya lebih baik berpeluang melakukan deteksi dini 1,8 kali dibandingkan dengan wanita yang pendidikannya rendah.

\section{DAFTAR PUSTAKA}

American Cancer Society. (2015). Cancer Facts \& Figures 2015. U.S.A.

Damailia. (2014). Faktor-Faktor Determinan Deteksi Dini Kanker Serviks Melalui Metode Pap Smear Tes Pada Pasangan Usia Subur Di Kelurahan Potrobangsan Wilayah Kerja Puskesmas Magelang Utara Kota Magelang Tahun 2014. Gaster. Vol XII No.2 Agustus 2015:99-107.

Dewi, Rosmala, dkk. (2012). Perubahan Pengetahuan dan Sikap Wanita yang Memiliki Pasangan Terhadap Pemeriksaan Pap Smear Sebelum dan Sesudah Diberikan Penyuluhan Deteksi Dini Kanker Serviks Dengan Pemeriksaan Pap Smear di Kelurahan Glugur Darat 1 Kecamatan Medan Timur Kota Medan Tahun 2012.
Departemen Kesehatan (Depkes) RI. (2008). Health Technology Assessment Indonesia, Skrining Kanker Leher Rahim Dengan Metode Inspeksi Visual Asam Asetat. 2008: 3,24-33.

.(2009).Buku Saku: Pencegahan Kanker Serviks dan Kanker Payudara. Jakarta: Direktorat Jenderal PP \& PL, Depkes RI.

Globocan. (2012). Ectimated Cancer Incidence, Mortality and Prevalence Worldwide in 2012. Diunduh http://globocan.iarc.fr/Pages/fact.

Gor Beverly J,Janice A Chilton, Pamela T Camingue and Richard A Hajek.(2010). Young Asian Americans' Knowledge and Perception of Cervical Cancer and The Human Papillomavirus. J Immigrant Minority Healt 2011-13: 81-86.

Gustiana, Dwikha dkk.(2014). FaktorFaktor Yang Berhubungan Dengan Perilaku Pencegahan Kanker Servik Pada Wanita Usia Subur.Jurnal Online Mahasiswa Bidang Ilmu Keperawatan Vol.1 No.2 2014 Hal 1-8.

Hanafi, Ocviyanti dkk. (2001). Efektivitas Pemeriksaan Inspeksi Visual Dengan Asam Asetat Oleh Bidan Sebagai Upaya Mendeteksi Lesi PraKanker Serviks. Indonesia J.Obstet Gynecol,2001:59-66.

ICO (Information Centre on HPV and Cancer). (2014). Human Papilloma Virus and Related Disease Report for Indonesia [Accessed 01 Mei 2016]<http://www.hpvcentre.net/stat istics/reports/ IDN.pdf.> 
International Agency for Research on Cancer (IARC). (2012). Cervical Cancer Estimated Incidence, Mortality and Prevalence Worldwide in 2012 WHO. France. Available from:http://globocan.iarc.fr/Pages/fa ct_sheets_cancer.aspx

Kemenkes RI.(2010). Keputusan Menteri Kesehatan

No.796/MENKES/SK/VII/2010

tentang Pedoman Teknik Pengendalian Kanker Payudara dan Kanker Leher Rahim. Jakarta: Kemenkes RI.

Program Nasional Gerakan
Pencegahan dan Deteksi Dini
Kanker Leher Rahim dan Kanker
Payudara. Jakarta: Kemenkes RI.
(2015). Stop Kanker Serviks.Jakarta: Pusat Data dan Informasi Kementerian Kesehatan RI.

Mulyati, Sri, dkk. (2015). Pengaruh Media Film Terhadap Sikap Ibu Pada Deteksi Dini Kanker Serviks. Kemas, Vol. 11, 2015: 16-24.

Ningrum, Roswati Dani. (2012). FaktorFaktor Yang Mempengaruhi Motivasi Ibu Mengikuti Detksi Dini Kanker Serviks Melalui Metode IVA Di Kabuaten Banyumas Tahun 2012. Jurnal Ilmiah Kebidanan , Vol.4 No.1, Edisi Juni 2013: 1-14.

Ostensson Ellinor, Susana Alder, K Miriam Elfstom, Karin Sundstrom, Niklas Zethreus, Marc Arbyn and Sonia Andersson. (2014). Barriers to and Facilitators of Compliance with Clinic-Based Cervical Cancer Screning: Population-Based Cohort Study of Women Aged 23-60 Years. Plos One Journal, May 26, 2015: 119.
Peirson, L; Donna; Warren, C. (2013). Screning For Cervical Cancer: a Systemati Review and MetaAnalysis. Biomed Central Journal, 2(13):1-14.

Szabova V, Svihrova V and Hudeckova V.(2014). Selected Risk Factors For Cervical Cancer and Barriers To Cervical Cancer Screning. Acta Medica Martiniana Journal, 2014 14/2: 25-30.

Taherian, Ali Akbar.(2002). Original Article Study of Risk Factors For Cervical Cancer a Case Controled Study In Isfahan-Iran. Department of Obstetric and Gyneclogy, Kuwait Medical Journal, 34(2): 128-132. 